\title{
Research on Effects of Chinese Confucianism on Japanese Literature
}

\section{Lili Dong}

\author{
College of Foreign Language, Jilin Agricultural University, Jilin, Changchun, China, 130118
}

\author{
Keywords: Effects, Chinese Confucianism, Japanese Literature
}

\begin{abstract}
Confucian thought is Chinese traditional thought and it is on behalf of the Chinese traditional culture, it has an important influence in the long history of development. Confucianism has got the world's attention and it has a profound impact on the development of the world. Confucian has the largest influence on many Asia countries, particularly in our neighboring countries, such as South Korea and Japan, especially in Japan. Confucian thought has a great influence on Japanese culture and customs and they are still highly heritage of Confucianism. This paper analyzes the impact of Confucianism on Japanese culture.
\end{abstract}

\section{Introduction}

Japanese scholar Nakamura said: "Just as all other nations history shows, a culturally backward nation is rarely voluntarily accept another more advanced national culture. Only in the recipient culture there are a number of other conditions will make the acceptance of foreign culture becomes easier. There are some certain obvious similarities of characteristics of people's way of thinking between Japanese and Chinese. We found that, in addition to China and Japan in certain aspects of the social structure and mode of production external similarities, some other conditions also helps to explain why the Japanese way of thinking was in favor of accepting digestion Chinese culture. indeed, in ancient China and Japan, there are many similar parallels, for example, the social structure in a relatively constant level of clan kinship system; self-sufficient agricultural economy and production; strong tradition respected conservative consciousness; severe visual sensory experience while ignoring the way of thinking abstract thinking; primitive religion and original way of thinking in folk abound; realism attitude towards life; tolerant attitude toward sex and the natural antipathy to asceticism; good at expression method of intuitive image Tech tradition, etc. this similarity is just the right medicine adapted to the exigencies of national life and culture of ancient Japan, which. It is the reason why the Japanese nation and actively introduce advanced Chinese culture drain income and production technology of the root causes behind the ancient.

It should be noted that the acceptance of a foreign national culture is the extent to which the nation needed with proportional; the way of a nation foreign culture Drain income and trade-offs depend on the basic spirit of the nation. Japanese national at the time of the introduction of China's advanced culture and the drain of income, it is the result of appropriate screening and abandoned, with the Japanese words is to be "filtered" or "purify" the Chinese thought. We can say that China's advanced culture and production technology into Japan have undergone some degree of deformation of taste, the Japanese in their own unique way to the changes and new commentary. This is prominently in Confucianism, Buddhism and Chinese poetry ideological tendency of the Japanese side, which fully demonstrated the open character of the Japanese nation. This fact, an open nation not only in the courage and the ability to select and receive drain of foreign culture, is more important is reflected in the screening, selection and digestion of foreign cultural re-creation capabilities. Japanese people in ancient China's advanced culture, and the West in modern times advanced culture and science and technology capacity and the introduction of screening and pumping close to choose aspect, showing Japanese people after all, openness and creativity of both peoples.

\section{The Overview of Confucianism}

Confucianism is a Chinese orthodoxy, representing Chinese traditional culture and it had been a 
standard and norm on social life and attitudes. "Benevolence, righteousness, propriety, wisdom, faith, forgive, loyalty, filial piety, brotherhood," which is the core of Confucian thought, every word contains a profound philosophy, is to regulate the personality requirements. The traditional three cardinal guides and the five permanent members are from Confucianism. "The Analects" is representative of Confucianism, with unshakable position in China's history and culture, is a typical literary works of Confucianism. "The Analects" of Confucius and his students together a compilation of fully reflects the Confucian politics and truth in life, it is typical of educational books, which contains many views far enough. For example, "The Analects • described the" in "three-line, must be my teacher choosing the good from it, their bad corrections." What this means is: a few people walking together, which must be I have to learn from the teacher. I should be studying for their excellent aspects to be corrected for the incorrect aspect. In fact, the essence of this sentence point of view is to have always had modest studious attitude, learning the strengths of others to abandon their weaknesses, self-reflection, self-cultivation and pay attention to their own progress, fully embody the truth in life. "Know is know, I do not know is I do not know, that is knowledge." This means to know is to know, do not know just do not know, this is smart. It is the man should hold an honest attitude, should not pretend to understand, is the basic requirement to get along with people. Confucianism contains a variety of educational perspectives, has won the attention of the world, Asian countries have had a profound impact.

\section{The Spread and Development of Chinese Confucianism in Japan}

Chinese Confucian classics are brought to Japan via Korea. Emperor Ōjin 15 August, the Korean peninsula Baekje king dispatched Mingjiao straight manifold people brought two good horses. This person can read Chinese classics, so Prince took him as a teacher. The Emperor asked: "Are there somebody clever than you in Baiji, Dr?" he replied: "The man named Wang Ren is very clever" The God Emperor immediately sent to invite Wang Ren in Baekje. In February the following year, Wang Ren came to Japan. Prince also thanks to Ren as a teacher. Wang Ren brought 10 volumes of "Analects" and 1 volume of "Thousand Character Classic".

After Confucianism was into Japan, it has gone through the early stages of Confucianism (Asuka, Nara, Heian period), Confucianism Zen became a vassal stage (Kamakura, chamber bite era), prime phase Confucianism (Edo) and Modern Confucianism debilitating stage.

Early effect produced of Confucianism in Japan was very limited, limited to royal Circle. At that time dedicated to study Confucianism and Tang culture provided "University Laos" (the equivalent of the Tang Dynasty Imperial College) also defines only accommodated children of the nobility from the conditions of the times, the fifth and sixth centuries of Japanese culture is still in its primitive religious culture dominant stage status, just entered the Japanese civil society has not yet entered the stage of conscious rational thought, in this state of mind is impossible for the Japanese Confucian rational spirit and insights occurred universal resonance. Early Confucian major role played by the Japanese royal family is to provide the basic model of cultural and political ideas of the ancient national management Mikado countries, such as the creation and application of the precepts of the system, political system, Royal Building, Chinese books and so on. From the beginning of Prince Shotoku "Suiko reform" to the Emperor Kotoku implementation of the "Taika Reform" (AD 603 in a 645 years) between the influence of Confucianism on Japanese upper class mainly in the full implementation of the concept of state Chinese Confucianism, "Heaven Warriors day, the country goes for the King" and other thought and its application in practice.

Confucianism became a vassal of the period of Zen Buddhism. Starting from the Kamakura period, a large number of classic Chinese Buddhism and the Japanese monks and Chinese monk brought to Japan and China passed Japan Song school time is roughly the mid-13th century, namely the Kamakura period. 14th century (room bite era beginning) the emergence of learning and explain Confucian scholars in Japanese aristocrats and monk, as the famous "five mountain monk" and later the formation of "Dr. Lords faction", "Sanan school", "Hainan school "Wait. This shows the popularity of Confucianism and the down trend from high society. At this point Confucianism to be studied are: strongly reconcile Confucianism, Buddhism and Shinto three religions, and even the 
way will be attached to each other to find similarities. Since Fuji Buddhism and Confucianism, Buddhism and thinking it means having commonality with the Zen. At that time, Buddhism is the national religion, which determines the Confucianism only in subordination Zen. Visible, Zen monk and learning and dissemination of Confucianism is not intended to promote Confucianism, but the Song school as a "co-channel", in order to promote Zen.

Edo period (also known as "Tokugawa era," 1603-1867) Confucianism is preached, explained the representative of the Song school Zhuzi characterized. Zhuzi after the 13th century introduced into Japan, after 350 years of propagation, to 1603, the Tokugawa shogunate was regarded as "official science", as the Edo period the ruling ideology. In the 260 years of the Tokugawa era, Japan Confucians is basically consistent with around Shinto and Taoism (God and Confucianism), Criticism on Buddhism accusations against Confucianism and Buddhism, asceticism, advocates of natural hylozoism Word of life, preached predestination and fatalism and other aspects of discrimination to be demonstrated and Song Studies. Among them, Japan Zhuzi pioneer Fujiwara Seika and Luo Shan in making Confucianism rid subordination Zen, Buddhism fierce criticism, advocate God and Confucianism, the Japanese Confucian ethics to development has played a historical guided drainage effect.

\section{The Impact of Confucianism on Japanese Literature}

The Influence of Confucianism on Japanese Literature in Cosmology. Chinese traditional Confucianism has been involved early on cosmology, there are records in the famous "Yi", describes the detached nature throughout the natural world, the universe, the universe is a manifestation of an important historical material. In the Western Han Dynasty, Dong Zhongshu the original cosmology certain supplement, the "Yi" in the "five elements" and Confucianism "Wuchang" perfect combination, pay attention to the yin and yang combination world combined. Such a world view of the Japanese had a profound impact, then has yin and yang combination, the heaven of the universe is set for the national faith, it attracted the attention of the Japanese. "Kojiki" is a literary work in Japan, is ordered by the Emperor of Japan compiled, recorded Japanese history, has a high historical value. In this literature, it reflects the Chinese culture, because this work is mostly in Chinese characters was compiled, we can imagine, the impact of Chinese culture on Japan; this work to the myth as a theme, which relates to the a lot of the universe: yin and yang describes the combination of heaven and earth heaven and earth, etc., with a clear description of the universe, the universe is a manifestation of representative works. While Confucianism also relates to cosmology views, and Japan's "Kojiki" would be similar. And "Yi" belong to the Warring States Period, Warring States Period in BC, while the "Kojiki" in AD 712 years, can be clearly concluded that Japan's "Kojiki" borrowed elaborated China's traditional Confucian Thought Universe .

Influence of Confucianism on Japanese Literature in Political View. Political view is the idea ofpolitical views or practices on the current socio-political development or political views and beliefs. Ancient political view is the definition of the ruling class, is a manifestation of the original social ruling class, the ruling system and ideas, has a certain political. On the political front, the Japanese Confucianism had a deep impact in the Japanese literature is also reflected. We all know that Japan believes the Emperor, the Emperor is the symbol of the country and the Japanese all swear allegiance to the emperor. In a reform in Japan, it introduced a large number of literary sources in China, as a reference to reform Japan's political system. "Analects of Confucius", "Book", "Book of Changes", which are the introduction of an object, according to the Japanese this information, the development of relevant constitutional and political system. Constitutionally entrenched ethnic peace, obey the Emperor, unity of thinking and other related content, it is political reform. In Japanese many political profiles, most cited the content of Confucianism, Confucianism appears more than once in the political thought of the Emperor implementation, the then Japan, Confucianism has penetrated into Japan's political domination, dominates Japan's political orientation and ideology.

Influence of Confucianism on Japanese Literature in Ethics Value. Ethics is some ethical issues opinions and views, to explore the importance of external ethical issues, human behavior is 
the norm and defined, fully embodies the life, values and world view. Ethics represent personal integrity and moral integrity, to reflect the vulgarity, abstinence features. Value of ethics is reflected in the value of life is an important part of personal character fully reflects the personal qualities. "Hōjōki" by Japanese writer duck out due to long work together and this work was written in the way of life after the frustrated duck Ming Yinshi long description. In the second part of the book describes the seclusion duck out because of the long, comfortable life of seclusion and silence, peace of mind, and fully reflects its otherworldly realm, so that authors put down political ambitions, attitude towards life and enjoy life. In the "Analects", it reflects the landscape longing for life, to promote simple, poor life style. Better life is not the luxury of living conditions, attitudes and beliefs but to enjoy life, not just stay between the interests and status and it is bound by the shackles of life. In the "Hōjōki", although the Ya Changming got career frustrations, he was optimistic and had a positive life, enjoy the idyllic life and also reflect on the value of life. Poor, optimistic and positive attitude towards life will be influenced by human ethics, education, people do not tie him to the secular, different goals in life will form no longer linger in the official salary, interpretation of humanity to achieve beauty.

\section{Conclusion}

With the social and economic development, Confucian thought spreads to the whole world through the Silk Road and the Atlantic trade routes. Japan is the country which is most affected by Confucianism, the messenger of all dynasties brought the Chinese Confucianism to Japan, many aspects of Japanese literature has fully draw our country's Confucian thought, it can be imagined the influence and infection force of Confucianism, this is an indisputable fact.

\section{References}

[1] Yan Guilin. Influence of Confucianism on Japanese literature [J] Jiannan literature (the first half), 2014.8:62-64.

[2] Xiaokai Yi, Gao Chunlu. Research on the Influence of Confucianism on Japanese literature [J] era literature (the second half), 2011.7:115-116.

[3] Zhao Xiaoping. The influence of Confucianism on Japanese literature [J] Suihua University, 2014.2: 68-70-78. 